\title{
PENGARUH KONSENTRASI MESOKARP SEMANGKA TERHADAP KARAKTERISTIK FISIKOKIMIA DAN MIKROBIOLOGI WATER KEFIR SEMANGKA KUNING (Citrullus lanatus (Thunb.))
}

\section{[Effect of Watermelon Mesocarp Concentration on Physicochemical and Microbiology Characteristic of Yellow Watermelon (Citrullus lanatus (Thunb.)) Water Kefir]}

\section{Rhema Nafiri Syalom, Sri Mulyani*, dan Anang Mohamad Legowo}

Program Studi Teknologi Pangan, Departemen Pertanian, Fakultas Peternakan dan Pertanian, Universitas Diponegoro, Semarang

*Email: srimulyani@lecturer.undip.ac.id

Diterima 13 Oktober 2020 / Disetujui 21 Januari 2021

\begin{abstract}
Yellow watermelon (Citrullus lanatus (Thunb.)) is a kind of horticulture commodity that contains high water content. There are three parts of yellow watermelon, namely the outer part (exocarp), the middle part with white color (mesocarp), and the fruit flesh (endocarp) that the mesocarp often becomes waste of the consumption of yellow watermelon. One of the development innovations for yellow watermelon is to process it into fermented beverage such as water kefir using the mesocarp so that there is no waste material. This research aims to know the effect of mesocarp concentration on yellow watermelon water kefir physicochemical and microbiology characteristics. The method of research was using Completely Randomized Design with one factor (mesocarp concentration). Treatment variation which is utilized the $0 \%(\mathrm{~V} / \mathrm{V}), 5 \%$ $(\mathrm{V} / \mathrm{V}), 10 \%(\mathrm{~V} / \mathrm{V}), 15 \%(\mathrm{~V} / \mathrm{V})$, and $20 \%(\mathrm{~V} / \mathrm{V})$ of mesocarp concentration. The research results show that the higher mesocarp concentration can increase the total of lactic acid and lactic acid bacteria, decrease the alcohol content and total of yeast, contribute to give antioxidants on water kefir, and mesocarp concentration does not have a real impact on viscosity.
\end{abstract}

Keywords: Mesocarp, Yellow Watermelon, Water Kefir

\section{ABSTRAK}

Semangka kuning (Citrullus lanatus (Thunb.)) merupakan salah satu komoditas hortikultura dengan kandungan air yang sangat tinggi. Pada semangka kuning terdapat tiga bagian yaitu bagian terluar (eksokarp), bagian tengah berwarna putih (mesokarp), dan daging buah (endokarp) yang mana dalam mengonsumsi semangka, mesokarp seringkali menjadi limbah. Inovasi pengolahan semangka kuning salah satunya dapat dijadikan minuman fermentasi water kefir dengan memanfaatkan mesokarp agar tidak menjadi bahan yang terbuang. Penelitian ini bertujuan untuk mengetahui pengaruh konsentrasi mesokarp terhadap karakteristik fisikokimia dan mikrobiologi water kefir semangka kuning. Metode penelitian menggunakan Rancangan Acak Lengkap dengan faktor tunggal (konsentrasi mesokarp). Variasi perlakuan yang digunakan adalah konsentrasi mesokarp $0 \%(\mathrm{v} / \mathrm{v}), 5 \%(\mathrm{v} / \mathrm{v}), 10 \%(\mathrm{v} / \mathrm{v}), 15 \%(\mathrm{v} / \mathrm{v})$, dan $20 \%(\mathrm{v} / \mathrm{v})$. Hasil penelitian menunjukan semakin tinggi konsentrasi mesokarp mampu meningkatkan total asam laktat dan total bakteri asam laktat, mampu menurunkan kadar alkohol dan total khamir, memberikan antioksidan pada water kefir, dan konsentrasi mesokarp tidak mempengaruhi viskositas.

Kata kunci: Mesokarp, Semangka Kuning, Water Kefir

\section{PENDAHULUAN}

Water kefir merupakan salah satu minuman fermentasi yang biasanya dibuat dengan menggunakan bahan dasar air, sari buah, ataupun air gula. Proses fermentasi water kefir memanfaatkan mikroba probiotik yang tersusun dari bakteri asam laktat (Lactobacillus, Lactococcus, dan
Leuconostoc), bakteri asam asetat (Acetobacter), dan khamir (Saccharomyces dan Candida) yang biasa disebut bibit water kefir (Purba dkk., 2018). Inovasi pengembangan produk water kefir ini dapat menjadi alternatif bagi pengonsumsi pangan non hewani ataupun yang memiliki intoleransi laktosa untuk mendapatkan senyawa prebiotik dari minuman fermentasi 
karena pada umumnya produk kefir diproses menggunakan bahan baku susu. Ciri khas yang dimiliki oleh water kefir terletak dari rasanya yang asam, bersifat alcoholic, terdapat sensasi soda saat dikonsumsi. Sensasi soda didapatkan karena adanya $\mathrm{CO}_{2}$ yang dihasilkan oleh khamir. Terciptanya flavour yang khas diperoleh dari kombinasi hasil fermentasi bakteri asam laktat (BAL), bakteri asam asetat (BAA), dan khamir yang mengubah gula menjadi senyawa-senyawa yang lebih sederhana. Mengonsumsi water kefir dapat memberikan manfaat seperti membantu menghilangkan mikroba patogen dalam tubuh (Setyowati dan Setyani, 2016). Salah satu buah yang dapat dijadikan bahan baku pembuatan water kefir adalah semangka kuning.

Semangka merupakan salah satu komoditas hortikultura yang mengandung kadar air tinggi. Pada daging buah semangka juga memiliki dua jenis warna yang familiar di Indonesia yaitu berwarna merah dan kuning. Adapun kandungan nutrisi yang terkandung didalamnya seperti air, karbohidrat, protein, lemak, serat, vitamin, antioksidan, fruktosa, dekstrosa, dan banyak lagi (Shanti dan Zuraida, 2016). Kandungan gula yang terdapat pada semangka kuning mencakup $51 \mathrm{mg} / \mathrm{g}$ fruktosa, $34 \mathrm{mg} / \mathrm{g}$ glukosa, dan $15 \mathrm{mg} / \mathrm{g}$ sukrosa (Sabeetha dkk., 2017). Ada tiga bagian yang terdapat pada semangka yaitu bagian terluar (eksokarp), bagian tengah berwarna putih (mesokarp), dan daging buah pada bagian dalam (endokarp). Pengolahan semangka kuning pada umumnya dikonsumsi secara langsung atau dijadikan jus, sehingga inovasi pengolahan lain sangatlah diperlukan. Pemanfaatan semangka kuning sebagai bahan baku water kefir harus diolah secara maksimal agar tidak terdapat bahan yang menjadi limbah.

Mesokarp atau albedo semangka merupakan lapisan yang memiliki tekstur tebal, berwarna putih, dan mengandung pektin yang potensial (Putri dkk., 2016). Persentase mesokarp pada satu buah semangka berkisar $30 \%$ dan sering menjadi bahan yang terbuang (Ho dan Dahri, 2016). Padahal, terdapat kandungan nutrisi pada mesokarp yang bisa untuk dimanfaatkan. Mesokarp memiliki antioksidan seperti sitrulin yang bermanfaat bagi tubuh. Sitrulin dapat berperan untuk menangkal radikal bebas dan memelihara kesehatan jantung dengan mengorganisir nitrogen oksida (Corleto dkk., 2019). Pemanfaatan mesokarp sudah dilakukan pada beberapa penelitian seperti kue, fruitghurt, selai, es krim, dan lain sebagainya. Penelitian sebelumnya memanfaatkan mesokarp semangka dengan metode ekstraksi dan dijadikan tepung menunjukkan adanya peningkatan antioksidan pada kue seperti fenol, sitrulin, arginin, serta terdapat juga serat (Al-sayed dan Ahmed, 2013). Selain itu, penelitian mengenai fruitghurt juga menunjukkan pemanfaatan mesokarp dapat mempengaruhi total asam, pH, dan kadar gula reduksi (Rahmawati dkk., 2016). Penelitian sebelumnya menunjukkan bahwa mesokarp memberikan peningkatan nilai gizi pada produk. Oleh karena itu, perlu inovasi pengolahan pasca panen berupa water kefir terhadap semangka kuning dengan memaksimalkan penggunaan mesokarp agar tidak menjadi bahan yang terbuang sekaligus menambah nilai fungsional pada produk.

Penelitan ini bertujuan untuk mengetahui pengaruh penambahan mesokarp dengan konsentrasi berbeda terhadap karakteristik fisikokimia dan mikrobiologi water kefir semangka kuning.

\section{BAHAN DAN METODE}

\section{Bahan dan Alat}

Bahan yang digunakan pada penelitian ini adalah delapan buah semangka kuning yang dibeli di Superindo Wahidin Semarang, bibit water kefir dari Industri Kristal Alga Jepang Yogyakarta, High Fructose Syrup

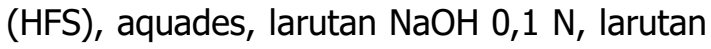
$\mathrm{NaCl}$ fisiologis $85 \%$, larutan etanol, larutan DPPH, indikator phenolphthalein 1\%, media de Mann Ragosa and Shape Agar MRSA merek Merck, media Potato Dextrose Agar 
(PDA) merek Merck. Peralatan penelitian meliputi timbangan analitik, termometer, pipet, piknometer, pipa Ostwald, stopwatch, gelas ukur, gelas beker, erlenmeyer, tabung reaksi, cawan petri, alat destilasi, buret, spektrofotometer UV-Vis merk SHIMADZU, laminar, autoklaf merk Hirayama.

\section{Metode}

Metode pada penelitian ini dilakukan dengan empat tahapan yaitu pembuatan sari mesokarp, pembuatan water kefir semangka kuning, uji variabel, dan analisis data.

\section{Pembuatan Sari Mesokarp}

Metode yang dilakukan yaitu mendapatkan sari mesokarp semangka yang mengacu pada penelitian sebelumya oleh Adnyana dkk. (2014). Mesokarp semangka dipisahkan dari kulit luarnya menggunakan pisau dan dilakukan pemotongan menjadi berukuran kecil. Setelah itu, potongan mesokarp dihancurkan menggunakan blender. Kemudian, dilakukan penyaringan untuk mendapatkan sari mesokarp dan disiapkan sesuai perlakuan untuk dilanjutkan ke pembuatan water kefir.

\section{Pembuatan Water Kefir Semangka Kuning}

Metode kedua merupakan pembuatan water kefir yang mengacu pada penelitian Yunivia dkk. (2019) dengan adanya modifikasi. Daging semangka kuning dihancurkan menggunakan blender dan disaring. Kemudian, sari semangka kuning dicampurkan dengan sari mesokarp sesuai dengan perlakuan masing-masing dan diaduk hingga merata. Setelah itu, dilakukan proses pasteurisasi pada suhu $70^{\circ} \mathrm{C}$ selama 30 detik, dan didiamkan hingga mencapai suhu $28^{\circ} \mathrm{C}$. Lalu, HFS sebanyak $8,5 \%$ dan bibit water kefir sebanyak 4\% dimasukkan ke setiap wadah perlakuan. Komposisi bahan pembuatan water kefir semangka dapat dilihat pada Tabel 1. Proses pembuatan water kefir dilanjutkan dengan tahapan inkubasi secara anaerob yang dilakukan selama 24 jam.

\section{Rancangan Percobaan}

Rancangan percobaan pada penelitian ini menggunakan Rancangan Acak Lengkap (RAL) dengan 5 perlakuan dan 4 ulangan. Perlakuan yang digunakan berupa konsentrasi sari mesokarp sebanyak $0 \%$ $(\mathrm{v} / \mathrm{v}), 5 \%(\mathrm{v} / \mathrm{v}), 10 \%(\mathrm{v} / \mathrm{v}), 15 \%(\mathrm{v} / \mathrm{v})$, dan $20 \%(\mathrm{v} / \mathrm{v})$.

\section{Pengujian Variabel}

Adapun variabel yang diamati meliputi karakteristik fisikokimia dan karakteristik mikrobiologi. Karakteristik fisikokimia mencakup viskositas (Cahyani dkk., 2019), kadar alkohol (Lestari dkk., 2018), total asam (Harijanti dkk., 2013), dan juga antioksidan (Dungir dkk., 2012), sedangkan karakteristik mikrobiologi mencakup total bakteri asam laktat (Rohman dkk., 2019) dan total khamir (Insani dkk., 2018).

\section{Analisis Data}

Analisis data pada penelitian ini menggunakan software SPSS 22.0 for windows dengan uji statistik ANOVA (Analysis of Varians) dengan taraf signifikansi 95\%. Apabila hasil ANOVA didapati hasil berbeda nyata, maka dilanjutkan dengan uji DMRT (Duncan Multiple Range Test). Analisis data pada antioksidan dengan metode DPPH diuji secara deskriptif menggunakan grafik dengan Microsoft Exce/ 2016.

\section{HASIL DAN PEMBAHASAN}

\section{KARAKTERISTIK FISIKOKIMIA}

$\begin{array}{llr}\text { Tabel 1. Komposisi } & \text { Bahan Water Kefir } \\ & \begin{array}{c}\text { Semangka Kuning } \\ \text { Konsentrasi Sari Mesokarp }\end{array} & \end{array}$

\begin{tabular}{lccccc}
\hline \multirow{2}{*}{ Bahan } & \multicolumn{5}{c}{ Konsentrasi Sari Mesokarp (v/v) } \\
\cline { 2 - 6 } & $\mathbf{0 \%}$ & $\mathbf{5 \%}$ & $\mathbf{1 0 \%}$ & $\mathbf{1 5 \%}$ & $\mathbf{2 0 \%}$ \\
\hline Sari semangka & 400 & 400 & 400 & 400 & 400 \\
kuning & $\mathrm{ml}$ & $\mathrm{ml}$ & $\mathrm{ml}$ & $\mathrm{ml}$ & $\mathrm{ml}$ \\
Sari mesokarp & $0 \mathrm{ml}$ & $20 \mathrm{ml}$ & $40 \mathrm{ml}$ & $60 \mathrm{ml}$ & $80 \mathrm{ml}$ \\
HFS & $34 \mathrm{ml}$ & $34 \mathrm{ml}$ & $34 \mathrm{ml}$ & $34 \mathrm{ml}$ & $34 \mathrm{ml}$ \\
$\begin{array}{l}\text { Bibit water } \\
\text { kefir }\end{array}$ & $16 \mathrm{~g}$ & $16 \mathrm{~g}$ & $16 \mathrm{~g}$ & $16 \mathrm{~g}$ & $16 \mathrm{~g}$ \\
\hline
\end{tabular}


Tabel 2. Viskositas, kadar alkohol dan total asam Water Kefir Semangka Kuning dengan Perlakuan Konsentrasi Sari Mesokarp

\begin{tabular}{cccc}
\hline $\begin{array}{c}\text { Konsentrasi } \\
\text { Sari Mesokarp }\end{array}$ & $\begin{array}{c}\text { Viskositas } \\
(\mathbf{c P})\end{array}$ & $\begin{array}{c}\text { Kadar } \\
\text { Alkohol } \\
\mathbf{( \% )}\end{array}$ & $\begin{array}{c}\text { Total } \\
\text { Asam } \\
\mathbf{( \% )}\end{array}$ \\
\hline $0 \%$ & 0,26 & $10,91^{\mathrm{d}}$ & $0,14^{\mathrm{a}}$ \\
$5 \%$ & 0,27 & $9,91^{\mathrm{d}}$ & $0,21^{\mathrm{a}}$ \\
$10 \%$ & 0,27 & $8,06^{\mathrm{c}}$ & $0,35^{\mathrm{b}}$ \\
$15 \%$ & 0,29 & $3,72^{\mathrm{b}}$ & $0,61^{\mathrm{c}}$ \\
$20 \%$ & 0,29 & $2,22^{\mathrm{a}}$ & $0,82^{\mathrm{d}}$ \\
\hline
\end{tabular}

Keterangan: data yang ditampilkan pada tabel merupakan nilai rata-rata. Superskrip huruf kecil yang berbeda pada kolom menunjukkan ada perbedaan nyata $(p<0,05)$.

\section{Viskositas}

Hasil uji statistik viskositas water kefir semangka kuning menunjukkan tidak ada perbedaan yang nyata untuk setiap perlakuan. Semangka kuning memiliki kandungan air yang sangat tinggi sehingga menimbulkan tekstur yang encer terhadap water kefir. Perlakuan sari mesokarp yang diberikan tidak memberikan pengaruh nyata karena kandungan airnya yang juga tinggi. Hal ini sesuai dengan pendapat Fila dkk. (2013) bahwa kadar air pada daging buah semangka berkisar $91,82 \%$ dan kadar air pada bagian albedo atau mesokarpnya sebanyak $67,75 \%$. Hal ini didukung oleh pendapat Puspitasari dkk. (2014) bahwa apabila kandungan air lebih besar dari kandungan padatan maka viskositas dalam suatu produk tidak meningkat.

Mesokarp memiliki pektin dengan golongan metoksil rendah yaitu sebesar 6,24\% (Octarya dan Ramadhani, 2014). Pektin dengan metoksil rendah tidak akan mengentalkan water kefir. Selain itu, pektin tidak mengentalkan water kefir ini karena juga dipengaruhi beberapa faktor seperti pemanasan, pengadukan, kadar gula, dan keasaman. Pada pembuatan water kefir dengan sari mesokarp ini, proses pengadukan dilakukan sebelum pasteurisasi berlangsung. Suhu dan waktu pasteurisasi yang digunakan juga tidak memicu pektin untuk membuat produk menjadi kental. Menurut (Saragih dkk., 2017), pektin akan mengental pada suhu $80^{\circ} \mathrm{C}$ hingga $100{ }^{\circ} \mathrm{C}$ selama 30 menit yang disertai pengadukan karena hal tersebut dapat memecah molekul kompleks ke molekul sederhana. Selain itu, Aziz dkk. (2018) menjelaskan jika pengentalan pektin akan terjadi pada kondisi kadar gula $58-75 \%$ dan $\mathrm{pH} 2,8-3,5$.

\section{Kadar Alkohol}

Kadar alkohol water kefir semangka kuning menunjukkan adanya penurunan seiring dengan meningkatnya konsentrasi sari mesokarp (Tabel 2). Kadar alkohol tertinggi ditunjukkan pada konsentrasi $0 \%$ sari mesokarp dan terendah pada konsentrasi $20 \%$ sari mesokarp. Fermentasi water kefir dengan penggunaan sari buah yang di dalamnya terkandung gula menjadi substrat bagi khamir untuk merubahnya menjadi alkohol dan $\mathrm{CO}_{2}$. Water kefir semangka kuning dengan konsentrasi sari mesokarp $0 \%$ memiliki kandungan gula dimaksimalkan oleh khamir untuk proses fermentasi. Semangka kuning memiliki jumlah gula yang lebih tinggi dibanding semangka merah seperti fruktosa $51 \mathrm{mg} / \mathrm{g}$, glukosa $34 \mathrm{mg} / \mathrm{g}$, dan sukrosa $15 \mathrm{mg} / \mathrm{g}$ (Sabeetha dkk., 2017). Semakin tinggi gula yang terdapat pada produk, maka kadar alkohol yang dihasilkan juga semakin tinggi karena jumlah substrat yang disediakan mampu memaksimalkan khamir untuk melakukan fermentasi.

Semakin tinggi konsentrasi sari mesokarp yang diberikan, kadar alkohol pada water kefir semakin menurun. Mesokarp semangka memiliki banyak serat pangan seperti pektin, selulosa, hemiselulosa, lignin, dan lain sebagainya yang dapat berperan sebagai adsorben alami. Serat pangan dapat mengikat gula seperti glukosa sehingga ketersediaannya berkurang (Santoso, 2011). Berkurangnya gula sebagai substrat membuat khamir tidak memproduksi alkohol dalam kadar yang tinggi. Kadar alkohol juga berbanding lurus dengan total khamir yang dapat dilihat pada Tabel 3. Menurunnya jumlah khamir akan mempengaruhi kadar alkohol pada water kefir yang merupakan hasil metabolismenya. 
Menurut Majelis Ulama Indonesia (2009), kadar alkohol pada minuman fermentasi seyogyanya tidak melebihi dari $1 \%$, sehingga walaupun hasil penelitian menunjukkan penurunan kadar alkohol seiring tingginya konsentrasi mesokarp, perlu dikaji ulang lebih lagi agar mencapai standar yang ada. Salah satunya dengan menambah lebih banyak konsentrasi sari mesokarp yang memiliki serat pangan berupa pektin, selulosa, hemiselulosa, dan lignin. Yao dkk. (2011) menjelaskan jika fermentasi minuman beralkohol sangat memerlukan pengontrolan pada pertumbuhan khamir agar tidak diperoleh alkohol yang berlebih dengan cara memanfaatkan polisakarida nabati seperti lignin, selulosa, dan hemiselulosa.

\section{Total Asam}

Total asam laktat pada water kefir semangka kuning dengan perlakuan penambahan sari mesokarp menunjukkan peningkatan meskipun pada konsentrasi $0 \%$ dan $5 \%$ tidak didapati beda nyata (Tabel 2 ). Total asam laktat paling tinggi didapati pada konsentrasi sari mesokarp 20\%. Hasil total asam laktat berbanding lurus dengan total BAL yang ditunjukkan pada Tabel 3. Semakin tinggi total BAL yang terkandung pada produk, maka asam laktat yang dihasilkan juga semakin banyak. Hal ini sesuai dengan pendapat Muizuddin dan Zubaidah (2015) bahwa fermentasi selama 24 jam akan memaksimalkan BAL untuk merombak gula supaya diperoleh asam laktat. Jumlah substrat juga mempengaruhi total asam laktat yang dihasilkan. Penggunaan HFS pada pembuatan water kefir ini juga dapat menjadi substrat yang digunakan BAL dalam memproduksi asam laktat pada produk. Menurut Yunivia dkk. (2019), HFS mampu mempercepat proses fermentasi yang dapat dilihat dari jumlah BAL dan total asam didalamnya.

Sari mesokarp semangka yang digunakan sebagai perlakuan, diduga memiliki senyawa prebiotik yang dapat dimanfaatkan oleh BAL untuk menghasilkan asam laktat. Semakin tinggi konsentrasi sari mesokarp yang diberikan, maka akan meningkatkan substrat yang dapat dimanfaatkan BAL untuk memproduksi asam laktat. Menurut Petkowitcz dkk. (2017) dan Romdhane dkk. (2016), mesokarp semangka memiliki pektin yang memiliki sifat fermentable sehingga dapat dimanfaatkan sebagai substrat mikroba. Konsentrasi yang semakin tinggi secara otomatis akan mengandung jumlah pektin, yang tinggi pula. Hal ini yang memicu terjadinya peningkatan total asam laktat. Penelitian sebelumnya (Hassani dkk., 2016; Kieserling dkk., 2019; Sabater dkk., 2020) menerangkan jika serat pangan berupa pektin mampu memberikan stimulasi pada pertumbuhan dan aktivitas BAL khususnya Lactobacillus sp. dalam melakukan proses fermentasi minuman.

Belum ada standar yang menetapkan total minimal atau maksimal asam laktat produk water kefir. Apabila mengacu pada standar Codex (2003) mengenai total asam laktat pada kefir susu fermentasi, telah dicantumkan bahwa pada kefir tersebut harus mengandung jumlah asam laktat minimal 0,6\%. Berdasarkan hal tersebut, water kefir pada penelitian ini yang memenuhi standar terdapat pada konsentrasi sari mesokarp $15 \%$ dan $20 \%$.

\section{Antioksidan}

Urutan antioksidan pada water kefir dari yang terendah hingga tertinggi berdasarkan dengan persentase inhibisi ditunjukkan oleh konsentrasi sari mesokarp $10 \%, 20 \%$, 15\%, 0\%, dan 5\%. Semakin tinggi persentase inhibisi, maka aktivitas antioksidan yang dihasilkan juga semakin tinggi (Lolaen dkk., 2013). Senyawa yang berperan sebagai antioksidan dari mesokarp adalah sitrulin. Hasil aktivitas antioksidan pada konsentrasi $10 \%, 15 \%$, dan $20 \%$ lebih rendah dibandingkan $0 \%$ dan $5 \%$ dapat disebabkan karena adanya pemanfaatan sitrulin sebagai substrat oleh BAL. Menurut Yu dkk. (2020), Lactobacillus brevis memiliki kemampuan untuk menurunkan kadar sitrulin untuk mencegah terjadinya pembentukan etil karbamat akibat reaksi sitrulin dengan etanol. Water kefir murni yang dibuat dengan bahan air, gula, dan bibit water kefir memiliki inhibisi sebesar 11\% (Alsayadi dkk., 
2013). Hal ini menunjukkan bahwa water kefir semangka kuning dengan penambahan sari mesokarp mampu meningkatkan aktivitas antioksidan. Selain sitrulin, adapun senyawa-senyawa lain yang menjadi antioksidan pada water kefir ini seperti asam askorbat, $\beta$-karoten, likopen, fenol, dan polifenol.

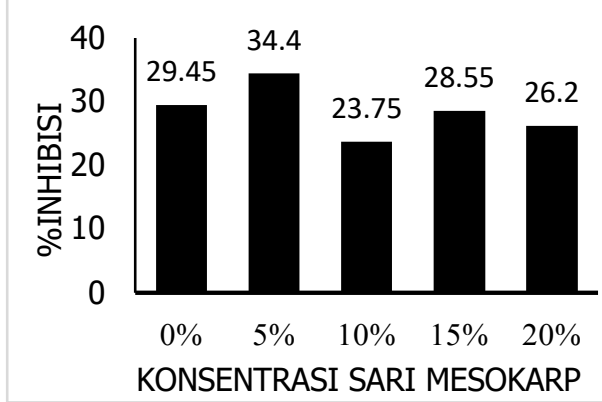

Gambar 1. Grafik Uji Antioksidan Water Kefir Semangka Kuning dengan Perlakuan Konsentrasi Sari Mesokarp

Aktivitas antioksidan ditentukan juga oleh aktivitas BAL khususnya strain Lactobacillus. Hal ini sesuai dengan pendapat Li dkk. (2012) bahwa bakteri jenis Lactobacillus plantarum terlibat dalam aktivitas antioksidan dengan mengeluarkan senyawa dari sel permukaan protein atau polisakarida yang mampu menurunkan radikal bebas dari DPPH. Senada dengan Fiorda dkk. (2016), BAL pada water kefir yaitu Lactobacillus, Lactococcus, Leuconostoc, dan Streptococcus sp meningkatkan aktivitas antioksidan dengan menangkap oksigen oksigen yang bersifat reaktif.

\section{Karakteristik Mikrobiologi}

Tabel 3.Total BAL dan Khamir Water Kefir Semangka Kuning dengan Perlakuan Konsentrasi Sari Mesokarp

\begin{tabular}{ccc}
\hline $\begin{array}{c}\text { Konsentrasi } \\
\text { Sari Mesokarp }\end{array}$ & $\begin{array}{c}\text { Total BAL } \\
(\log \mathbf{~ c f u / m I )}\end{array}$ & $\begin{array}{c}\text { Total Khamir } \\
(\log \mathbf{~} \mathbf{f u} / \mathbf{m l})\end{array}$ \\
\hline $0 \%$ & $7,21^{\mathrm{a}}$ & $8,03^{\mathrm{e}}$ \\
$5 \%$ & $7,64^{\mathrm{b}}$ & $7,84^{\mathrm{d}}$ \\
$10 \%$ & $7,81^{\mathrm{c}}$ & $7,72^{\mathrm{c}}$ \\
$15 \%$ & $7,92^{\mathrm{d}}$ & $7,42^{\mathrm{b}}$ \\
$20 \%$ & $7,96^{\mathrm{d}}$ & $7,22^{\mathrm{a}}$ \\
\hline Keterangan: data yang ditampilkan pada tabel \\
merupakan nilai rata-rata. Superskrip huruf kecil yang \\
berbeda pada kolom menunjukkan ada perbedaan nyata \\
(p<0,05).
\end{tabular}

\section{Total Bakteri Asam Laktat (BAL)}

Water kefir semangka kuning menunjukkan perlakuan penambahan sari mesokarp ada peningkatan total BAL (Tabel 3). Peningkatan jumlah BAL pada water kefir paling penting dipengaruhi oleh ketersediaan substrat. HFS menjadi sumber nutrisi bagi BAL untuk memproduksi asam laktat. Hal ini sesuai dengan pendapat Tu dkk. (2019) dan Xu dkk. (2019) bahwa fruktosa dapat menjadi sumber karbon bagi BAL sekaligus berperan sebagai electron acceptor pada produk fermentasi seperti water kefir. Selain HFS, pada bahan utama water kefir menggunakan semangka kuning yang didalamnya juga terdapat gula dan juga menjadi sumber substrat bagi BAL.

Mesokarp yang digunakan sebagai perlakuan memiliki salah satu kandungan yang bersifat fermentable yaitu pektin. Adanya pektin pada proses fermentasi ini dapat mendukung BAL dalam peningkatan pertumbuhannya. Pektin menambah sumber substrat bagi BAL sehingga pada proses fermentasi dapat berjalan secara optimal. Menurut Ho dkk. (2017), pektin berpotensi menjadi prebiotik karena BAL khususnya Lactobacillus dan Bifidobacterium memiliki kemampuan untuk melakukan degradasi polisakarida dengan memanfaatkan enzim intraselulernya. Selain itu, mesokarp juga mengandung serat-serat pangan lainnya seperti selulosa dan hemiselulosa yang juga dapat dimanfaatkan oleh BAL. Salah satu jenis BAL yang dapat menghidrolisis senyawa tersebut adalah Lactobacillus plantarum karena memiliki enzim intraseluler berupa amilase. Susunan serat pangan polisakarida akan dihidrolisis menjadi senyawa sederhana dengan enzim intraseluler dan akan dihasilkan asam laktat sebagai metabolit. Hal ini sesuai dengan pendapat Mazzoli dkk. (2014) bahwa BAL dengan golongan bakteri amilolitik seperti Lactobacillus plantarum menghidrolisis polisakarida dalam fermentasi sangat efektif dengan proses enzimatis dan akan menghasilkan asam laktat. Senada dengan pendapat Okano dkk. (2010) bahwa BAL yang tergolong bakteri amilolitik mampu menghidrolisis polisakarida menjadi 
oligosakarida dan monosakarida dengan memanfaatkan enzim amilase saat fermentasi.

Menurut Codex (2003), standar total BAL pada kefir harus mengandung minimal 1 $\times 10^{7} \mathrm{cfu} / \mathrm{ml}$, yang sudah ditunjukkan bahwa water kefir semangka kuning pada penelitian sudah mencapai standar.

\section{Total Khamir}

Total khamir water kefir semangka kuning menunjukkan adanya perbedaan nyata untuk setiap perlakuan. Semakin tinggi konsentrasi yang diberikan, total khamir yang tumbuh pada produk semakin menurun (Tabel 3). Khamir akan memproduksi alkohol dan $\mathrm{CO}_{2}$ sebagai metabolit dari proses fermentasi pada water kefir. Menurut Syrokou dkk. (2019) dan Lu dkk. (2014), Saccharomyces cerevisiae merupakan salah satu khamir yang paling dominan dalam menghasilkan alkohol pada water kefir karena karakterisiknya tahan dalam $\mathrm{pH}$ rendah, dapat tumbuh dalam kondisi aerob atau anaerob, dan dapat bertahan dengan suasana alcoholic. Water kefir dengan konsentrasi sari mesokarp $0 \%$ memiliki total khamir paling tinggi karena kandungan gula dari HFS dan sari buah semangka kuning yang bisa lebih optimal dimanfaatkan sebagai substrat. Khamir mengubah gula yang terdapat pada HFS dan sari buah semangka menjadi alkohol dan $\mathrm{CO}_{2}$. Pertumbuhan khamir dan BAL berbanding terbalik pada penelitian ini, karena adanya enzim yang dimiliki BAL untuk mendegradasi komponen pada mesokarp sebagai cadangan substrat.

Semakin tinggi konsentrasi sari mesokarp yang diberikan sebagai perlakuan pada water kefir menunjukkan penurunan total khamir. Mesokarp semangka memiliki kandungan serat pangan, protein, dan polifenol (Hussain dkk., 2019). Menurut Nguela dkk. (2019), adanya polifenol dan protein yang berinteraksi dalam suatu produk dapat melemahkan rangsangan khamir terhadap nutrien sehingga pertumbuhannya terhambat. Polifenol juga mampu menembus dinding sel khamir yang menyebabkan autolisis. Selain itu, Chen dkk. (2017) juga menerangkan bahwa peningkatan BAL akan menciptakan kondisi asam yang mampu menurunkan pertumbuhan khamir. Penelitian ini dapat dilihat bahwa mesokarp mampu meningkatkan pertumbuhan BAL (Tabel 5.), sehingga tercipta suasana asam yang mempengaruhi pertumbuhan khamir. Kondisi asam tidak hanya dibentuk oleh BAL, namun bibit water kefir juga mencakup bakteri asam asetat yang juga mengeluarkan asam asetat sebagai metabolit.

\section{KESIMPULAN}

Penambahan mesokarp dengan konsentrasi berbeda memberikan peningkatan terhadap total asam dan total bakteri asam laktat (BAL) dan menurunkan kadar alkohol dan total khamir. Konsentrasi mesokarp tidak mempengaruhi viskositas water kefir semangka kuning. Penambahan sari mesokarp mampu meningkatkan aktivitas antioksidan dari water kefir murni. Perlakuan terbaik untuk penelitian ini adalah water kefir semangka kuning dengan konsentrasi sari mesokarp $20 \%$.

\section{DAFTAR PUSTAKA}

Adnyana, I. K., N. D. Arlinda, dan D. Safitri. 2014. Efek Anti Lelah Air Mesokarp Semangka Kuning (Citrullus lanatus Thunb.) Tanpa Biji. Jurnal IImiah Farmasi. 2(2): 1-6. DOI: 10.26874/kjif.v212.27.

Alsayadi, M., Y. Aljawfi, M. Belarbi, and F. Z. Sabri. 2013. Antioxidant Potency of Water Kefir. Journal of Microbiology, Biotechnology, and Food Sciences. 2(6): 2444-2447.

Al-Sayed, H. M. A., and A. R. Ahmed. 2013. Utilization of Watermelon Rinds and Sharlyn Melon Peels as a Natural Source of Dietary Fiber and Antioxidants in Cake. Annals of Agriculture Science Journal. 58(1): 8395. DOI: 10.1016/j.aoas.2013.01.012.

Aziz, T., M. E. G. Johan, dan D. Sri. 2018. Pengaruh Jenis Pelarut, Temperatur, dan Waktu terhadap Karakterisasi 
Pektin dari Hasil Ekstraksi Kulit Buah Naga (Hylocereus polyrhizus). Jurnal Teknik Kimia. 24(1): 17-27. DOI: 10.36706/jtk.y24il.413.

Cahyani, S. O., B. Dwiloka, dan H. Rizqiati. 2019. Perubahan Sifat Fisikokimia dan Mutu Hedonik Kefir Air Kelapa Hijau (Cocos mucifera L.) dengan Penambahan High Fructose Syrup (HFS). Jurnal Teknologi Pangan. 3(1): 96-103. DOI: 10.14710/jtp.3.1.96-103.

Chen, Y., Y. Huang, Y. Bai, C. Fu, M. Zhou, B. Gao, C. Wang, D. Li, Y. Hu, and N. Xu. 2017. Effects of Mixture Cultures of Saccharomyces cerevisiae and Lactobacillus plantarum in Alcoholic Fermentation on The Physicochemical and Sensory Properties of Citrus Vinegar. LWT - Food Science and Technology. 84(1): 753-763. DOI: 10.1016/j.Iwt.2017.06.032.

Codex Alimentarius Commision. 2003. Codex Standard for Fermented Milks. CODEX STAN 243-2003.

Corleto, K. A., J. Singh, G. K. Jayaprakasha, and B. S. Patil. 2019. A Sensitive HPLCFLD Method Combined with Multivariate Analysis for The Determination of Amino Acids in LCitrulline Rich Vegetables. Journal of Food and Drug Analysis. 27(3): 717728. DOI: $10.1016 /$ j.jfda.2019.04.001.

Dungir, S. G., D. G. Katja, dan V. S. Kamu. 2012. Aktivitas Antioksidan Ekstrak Fenolik dari Kulit Buah Manggis (Garcinia mangostana L.). Jurnal MIPA UNSRAT Online. 1(1): 1-15. DOI: 10.35579/jm.1.1.2012.424.

Fila, W. A., E. H. Itam, J. T. Johnson, M. O. Odey, E. E. Effiong, K. Dasofunjo, and E. E. Ambo. 2013. Comparative Proximate Composition of Citrullus lanatus, Squash Curcubita pepo\%, and Rambutan Nephelium lappaceum. International Journal of Science and Technology. 2(1): 81-88.

Fiorda, F. A., G. V. de Melo Pereira, V. Thomaz-Soccol, A. P. Medeiros, S. K. Rakshit, and C. R. Soccol. 2016. Development of Kefir-Based Prebiotic
Beverages with DNA Protection and Antioxidant Activities Using Soybean Hydrolyzed Extract, Colostrum, and Honey. LWT - Food Science and Technology. 68(1): 690-697. DOI: 10.1016/j.Iwt.2016.01.003.

Harijanti, I. A. P., Y. B. Pramono, dan S. Mulyani. 2013. Total Asam, Viskositas, dan Kesukaan pada Yoghurt Drink dengan Sari Buah Manga (Mangifera Indica) Sebagai Perisa Alami. Jurnal Aplikasi Teknologi Pangan. 2(2): 104107.

Hassani, M., A. Sharifi, A. M. Sani, and B. Hassani. 2016. Growth and Survival of Lactobacillus acidophilus and Bifidobacterium bifidum in Probiotic Yogurts Enriched by Barberry Extract. Journal of Food Safety. 36(4): 503507. DOI: $10.1111 /$ jfs. 12269.

Ho, L. H., and N. C. Dahri. 2016. Effect of Watermelon Rind Powder on Physicochemical, Textural, and Sensory Properties of Wet Yellow Noodles. Journal of Food. 14(3): 465-472.DOI: 10.1080/19476337.2015.1134672.

Ho, Y., C. Lin, and M. Wu. 2017. Evaluation of The Prebiotic Effects of Citrus Pectin Hydrosylate. Journal of Drug and Analysis. 25(1): 550-558. DOI: 10.1016/j.jfda.2016.11.014.

Hussain, N., N. Azhar, and S. G. S. Rajoo. 2019. Effects of Thermosonication on Watermelon Rind-Honey Beverage. Italian Journal of Food Science. 31(4): 631-651. DOI: 10.14674/IJFS-1345.

Insani, H., H. Rizqiati, dan Y. Pratama. 2018. Pengaruh Variasi Konsentrasi Sukrosa terhadap Total Khamir, Total Padatan Terlarut, Kadar Alkohol, dan Mutu Hedonik pada Water Kefir Buah Naga Merah (Hyloreceus polyrhizus). Jurnal Teknologi Pangan. 2(1): 90-95. DOI: 10.14710/jtp.2.2.90-97.

Kieserling, K., T. M. Vu, S. Drusch, and S. Schalow. 2019. Impact of Pectin-Rich Orange Fibre on Gel Characteristic and Sensory Properties in Lactic Acid Fermented Yoghurt. Food Hydrocolloids. 94(1): 152-163. DOI: 10.1016/j.foodhyd.2019.02.051. 
Lestari, M. W., V. P. Bintoro, dan H. Rizqiati. 2018. Pengaruh Lama Fermentasi terhadap Tingkat Keasaman, Viskositas, Kadar Alkohol, Mutu Hedonik Kefir Air Kelapa. Jurnal Teknologi Pangan. 2(1): 8-13.DOI: 10.14710/jtp.2.1.\%25p.

Li, W., M. Mutuvulla, X, Chen, M. Jiang, and M. Dong. 2012. Isolation and Identification of High ViscosityProducing Lactic Acid Bacteria from A Traditional Fermented Milk In Xinjiang An Its Role in Fermentation Process. European Food Research and Technology. 235(1): 497-505. DOI: 10.1007/s00217-012-1779-7.

Lolaen, L. A. C., Fatimawali, dan G. Citraningtyas. 2013. Uji Aktivitas Antioksidan Kandungan Fitokimia Jus Buah Gandaria (Bouea macrophylla Griffith). Pharmacon: Jurnal IImiah Farmasi UNSRAT. 2(2): 1-8.

Lu, M., X. Wang, G. Sun, B. Qin, J. Xiao, S. Yan, Y. Pan, and Y. Wang. 2014. Fine Structure of Tibetan Kefir Grains and Their Yeast Distribution, Diversity, and Shift. PLOS ONE. 9(6): 1-10. DOI: 10.1371/journal.pone.0101387.

Majelis Ulama Indonesia. 2009. Fatma Majelis Ulama Indonesia Nomor 11 tentang Hukum Alkohol. Himpunan Fatma Majelis Ulama Indonesia, Jakarta.

Mazzoli, R., F. Bosco, I. Mizrahi, E. A. Bayer, and E. Pessione. 2014. Towards Lactic Acid Bacteria-Based Biorefineries. Biotechnology Advanced. 32(7): 12161236.

DOI:10.1016/j.biotechadv.2014.07.005.

Muizuddin, M., dan E. Zubaidah. 2015. Studi Aktivitas Antibakteri Kefir Teh Daun Sirsak (Anonna muricata linn.) dari Berbagai Macam Merk Teh Daun Sirsak di Pasaran. Jurnal Pangan dan Agroindustri. 3(4): 1662-1672.

Nguela, M. J., A. Vernhet, A. Julien-Ortiz, N. Sieczkowski, and J. R. Mouret. 2019. Effect of Grape Must Polyphenols on Yeast Metabolism During Alcoholic Fermentation. Food Research
International. 121(1): 165-171. DOI: 10.1016/j.foodres.2019.03.038.

Octarya, Z., dan A. Ramadhani. 2014. Ekstraksi dan Karakterisasi Pektin dari Limbah Kulit Semangka Menggunakan Ekstrak Enzim Aspergillus niger. Jurnal Agroteknologi. 4(2): 27-31.

Okano, K., T. Tanaka, C. Ogino, H. Fukuda, and A. Kondo. 2010. Biotechnological Production of Enantiomeric Pure Lactic Acid from Renewable Resources: Recent Achievements, Perspectives, and Limits. Applied Microbiology and Biotechnology. 85(1): 413-423. DOI: 10.1007/s00253-009-2280-5.

Petkowicz, C. L. O., L. C. Vriesmann, and P. A. Williams. 2017. Pectins from Food Waste: Extraction, Characterization, and Properties of Watermelon Rind Pectin. Food Hydrocolloids. 65(1): 5767. 10.1016/j.foodhyd.2016.10.040.

Purba, A. P., B. Dwiloka, dan H. Rizqiati. 2018. Pengaruh Lama Fermentasi terhadap Bakteri Asam Laktat (BAL), Viskositas, Aktivitas Antioksidan, dan Organoleptik Water Kefir Anggur Merah. Jurnal Teknologi Pangan. 2(1): 49-51. DOI: $10.14710 / j t p .2 .1 . \% 25 p$.

Putri, G. N., N. H. R. Parnanto, dan A. Nursiwi. 2016. Pengaruh Penambahan Gum Arab terhadap Karakteristik Fisik, Kimia, dan Organoleptik Fruit and Vegetable Leather dari Albedo Semangka (Citrullus lanatus Schard.) dan Wortel (Daucus carota). Jurnal Teknosains Pangan. 5(3): 20-30.

Rahmawati, I., Darmawati, dan I. Mahadi. 2016. Pembuatan Fruitghurt dari Lapisan Putih (Mesokarp) Kulit Semangka (Citrullus Vulgaris) Berdasarkan Lama Fermentasi dan Analisis Potensi Rancangan Lembar Kerja Siswa Pada Pembelajaran Biologi SMA. Jurnal Online Mahasiswa Fakultas Keguruan dan IImu Pendidikan. 3(2): 1-15.

Rohman, A., B. Dwiloka, dan H. Rizqiati. 2019. Pengaruh Lama Fermentasi terhadap Total Bakteri Asam Laktat, 
Total Khamir, dan Mutu Hedonik Kefir Air Kelapa Hijau (Cocos mucifera). Jurnal Teknologi Pangan. 3(1): 127133. DOI: $10.14710 /$ jtp.3.1.127-133.

Romdhane, M. B., A. Haddar, I. Ghazala, K. B. Jedou, C. B. Helbert, and S. EllouzChaabouni. 2016. Optimization of Polysaccharides Extraction from Watermelon Rinds: Structure, Functional, and Biological Activities. Food Chemistry. 216(1): 355-364. DOI: 10.1016/j.foodchem.2016.08.056.

Sabater, C., C. Abad-Garcia, P. DelgagoFernandez, N. Corzo, and A. Montilla. 2020. Carbohydrate Fraction Characterisation of Functional Yogurts Containing Pectin and Pectic Oligosaccharides Through Conventional Networks. Journal of Food Composition and Analysis. 90(1): 1-13. DOI: 10.1016/j.jfca. 2020.103484.

Sabeetha, S., I. Amin, and M. Y. B. Nisak. 2017. Physico-chemical Characteristic of Watermelon in Malaysia. Journal of Tropical Agriculture and Food Science. 45(2): 209-223.

Santoso, A. 2011. Serat Pangan (Dietary fiber) dan Manfaatnya Bagi Kesehatan. Magistra. 23(75): 35-40.

Saragih, M. A., V. S. Johan, dan U. Pato. 2017. Pengaruh Penambahan Kelopak Rosella terhadap Mutu Sensori Permen Jelly dari Albedo Semangka. Jurnal Online Mahasiswa Fakultas Pertanian Universitas Riau. 4(1): 1-12.

Setyowati, H., dan W. Setyani. 2016. Kefir: A New Role as Neutraceuticals. Jurnal Kedokteran dan Kesehatan Manusia. 7(5): 200-209.

Shanti, N. M., dan R. Zuraida. 2016. Pengaruh Pemberian Jus Semangka terhadap Penurunan Tekanan Darah Lansia. Jurnal Majority. 5(4): 117-123.

Syrokou, M. K., M. Papadelli, I. Ntaikou, S. Paramithiotis, and E. H. Drosinos. 2019. Sugary Kefir: Microbial Identification and Biotechonoligical Properties. Beverages. 5(4): 1-18. DOI: $10.3390 /$ beverages5040061.
Tu, C., F. Azi, J. Huang, X. Xu, G. Xing, and M. Dong. 2019. Quality and Metagenomic Evaluation of A Novel Functional Beverage Produced from Soy Whey Using Water Kefir Grains. LWT - Food Science and Technology. 113(1): 1-10. DOI: 10.1016/j.Iwt.2019. 108258.

Xu, D., J. Bechtner, J. Behr, L. Eisenbach, A. J. Geißler, and R. F. Vogel. 2019. Lifestyle of Lactobacillus hordei Isolated from Water Kefir Based on Genomic, Proteomic and Physiological Characterization. International Journal of Food Microbiology. 290(1): 141-149. DOI:

10.1016/j.ijfoodmicro.2018.10.004.

Yao, W., X. Wu, J. Zhu, B. Sun, Y. Y. Zhang, and C. Miller. 2011. Bacterial Cellulose Membrane - A New Support Carrier for Yeast Immobilization for Ethanol Fermentation. Process Biochemistry. 46(1): 2054-2058. DOI: 10.1016/j.procbio.2011.07.006.

Yu, W., G. Xie, D. Wu, X. Li, and J. Lu. 2020. A Lactobacillus brevis Strain Citrulline Re-uptake Activity for Citrulline Ethyl Carbamate Control During Chinese Rice Wine Fermentation. Food Biochemistry. 36(1): 1-5. DOI: 10.1016/j.fbio.2020.100612.

Yunivia, Y., B. Dwiloka, dan H. Rizqiati. 2019. Pengaruh Penambahan High Fructose Syrup (HFS) terhadap Perubahan Sifat Fisikokimia dan Mikrobiologi Kefir Air Kelapa Hijau. Jurnal Teknologi Pangan. 3(1): 116-120. DOI: 10.14710/jtp.3.1.116-120. 